\title{
JOURNAL.RU
}

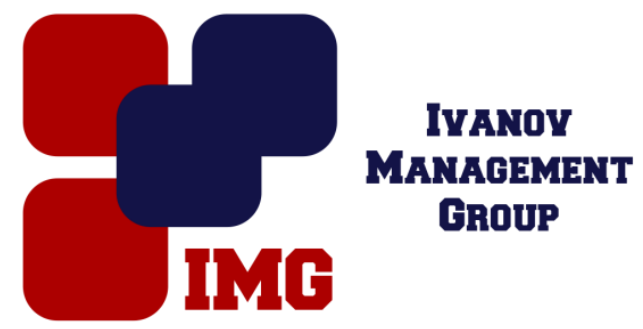

\author{
Акбашева Д. М., Кушхова Э.М., Казанокова А.К. \\ Северо-Кавказская государственная гуманитарно технологическая академия \\ Черкесск, Россия
}

doi: 10.18411/1j-30-04-2017-1-03

idsp 000001:1j-30-04-2017-1-03

\section{Импортозамещение в животноводстве}

За минувшие годы в сфере животноводства произошло большое количество хороших перемен. Главным шагом в качественном изменении и модернизации животноводческих комплексов явилась приоритетная задача национального проекта «Развитие АПК» и Государственный проект реализации сельского хозяйства.

В 2014 году производство скота и птицы на убой в живом весе, во всех хозяйственных категориях, по данным Росстата составил 12,91 млн. тонн, это на 4,2\% или 515,6 тыс. тонн выше, чем в 2013 году в сельскохозяйственных организациях производство скота и птицы на убой повысилось на 7,9\%, в фермерских хозяйствах - на $12,1 \%$, а в хозяйствах населения оно снизилось на $5,0 \%$.

Главный рост производства случилось за счет повышения производства свиней на убой на $3,9 \%$ и птицы - на 7,1\%. В том числе возросло производство овец и коз на убой в живом весе на $6,2 \%$.

Наибольшее повышение объемов производства 100,6 тыс. тонн составили хозяйства Курской области. В разы увеличилось производство скота и птицы на убой в Тамбовской области на 80,0 тыс. тонн, в Республике Марий Эл - 59,7 тысячи тонн, в Челябинской области - 60,1 тыс. тонн, в Брянской области - 46,9 тыс. тонн, в Республике Мордовия - 39,6 тыс. тонн. С начала 2015 года поголовье КРС в хозяйствах всех категорий по данным Росстата составил 20,2 млн. голов, в том числе коров - 9,1 млн. голов, или 98,5 процента. Поголовье свиней равно 20,1 млн. голов, овец и коз 23,6 млн. голов, 99,9\% и птицы $-515,4$ млн голов, или $105,4 \%$. 
В 2015 году производство скота на убой в живом весе во всех категориях хозяйств составил 3,1 млн. тонн, это на 0,8\% меньше уровня 2014 года, несмотря на то, что во многих регионах рост производства крупного рогатого скота на убой в живом весе меньше.

Производство крупного рогатого скота на убой поднялось на 6,9 тыс. тонн в Республике Башкортостан, Самарской области - 8,1 тыс. тонн, в Ростовской области - 5,9 млн. тонн, Ставропольский край - на 6,1 тыс. тонн. В 2014 году часть производства говядины в общем объеме производства мяса составил $19,3 \%$.

Гораздо выросло население в Брянской области, Карачаево-Черкессии, Оренбургской области, Пензенской области. В прошлом году, производство продуктов из мяса и помесного скота, крупного рогатого скота на убой в живом весе составил 237,8 тыс. тонн, это на $8,9 \%$ выше, чем в 2014 году.

За минувшие годы в свиноводстве России случились незначительные приятные перемены. Отрасль стала конкурентоспособной и начала привлекать инвесторов.

С 2010 года, благодаря активной технологической модернизации введено в эксплуатацию и реконструировано 456 свиноводческих комплексов и ферм. Благодаря этому стало возможно произведение более 500 тысяч тонн свиней на убой в живом весе. В 2014 году производство свиней на убой в живом весе во всех категориях хозяйств составил 3,56 млн. тонн, до 157,9 тыс. тонн, или на $3,8 \%$ выше, чем в 2013 году, в том числе в сельскохозяйственных отраслях - 2,78 млн. тонн, или на 15,7\% выше, чем в прошлом году.

В 2014 году доля свинины в общем производстве мяса составил 33,1\%. Самодостаточность свинины в прошлом году составил 79,9\%. Потребление свинины на душу населения за предыдущий год составил 25,5 кг, хотя рекомендуемая рациональная норма потребления- 17 кг на человека в год.

Производство птицы на убой в живом весе во всех категориях хозяйств в 2014 году составило 5,67 млн. тонн, это на 5,7\% до 310,5 тыс. тонн выше, чем в 2013 году, в том числе в сельскохозяйственных отраслях - 5,1 млн. тонн, это на $6,9 \%$ или на 336,7 тыс. тонн выше, чем за соответствующий период прошлого года. Организация, предоставляющий наибольший прирост производства птицы на убой в живом весе в 2014 году: Курская область - 59,9 тыс. тонн, Республика Марий Эл - 59,4 тыс. тонн, Челябинская область - 39,9 тыс. тонн, Брянская область - 36,7 тыс. тонн, Республика Мордовия - 38,7 тыс. тонн. Потребление 
яиц на душу населения в прошлом году составило 278 единиц, а рекомендуемая рациональная норма потребления - 250 единиц на человека в год.

Для того, чтобы достичь импортозамещения в племенном производстве, уменьшении риска эпизоотийных заболеваний, выравнивания рисков с точки зрения вероятных ограничений поставок генетического материала из-за границы. В Государственном проекте предусмотрена совокупность мер по созданию дополнительных и по формированию существующих племенных и генетических центров в животноводстве. Осуществление мер по созданию дополнительных и совершенствованию имеющихся племенных и генетических центров в животноводстве сформирует внутренний генофонд уникальных пород и линий сельскохозяйственных животных и обеспечит устойчивую динамику роста животноводства.

\section{Литература}

1. Башкатов Б.И. Статистика сельского хозяйства.- М.: <Экмос>,2015.- 352c.

2. Савицкая Г. В. Анализ хозяйственной деятельности предприятий АПК; Инфра-М - , 2012. $-656 \mathrm{c}$.

3. Научно-практический журнал для руководителей и главных специалистов АПК. Животноводство России. Спецвыпуск по птицеводству 1 / 2016. 